\title{
Reconstructing the formation of a costal aquifer in Nampula province, Mozambique, from ERT and IP methods for water prospection
}

\author{
F. J. Chirindja ${ }^{1,2} \cdot$ T. Dahlin ${ }^{1}$ D. Juizo ${ }^{2}$ F. Steinbruch ${ }^{3}$
}

Received: 25 October 2016/Accepted: 23 December 2016/Published online: 30 December 2016

(C) The Author(s) 2016. This article is published with open access at Springerlink.com

\begin{abstract}
In continental margin basins, the hydrogeological setting is complex due to transgression/regression events that removed old sediments in the basin and formed new geologic units. Due to the geological complexity, the use of vertical electrical sounding has proven to be insufficient for groundwater explorations. The lack of understanding the geological underground has resulted in many boreholes with low yield or poor water quality. By performing electrical resistivity tomography (ERT) and induced polarization (IP) measurements in 11 villages in Mongicual district, three different layers covering the basement were identified: a weathered autochthon layer, a weathered allochthon layer (paleo-coastal dune) and eolian white sand layer. The drilling at successful boreholes penetrates formations where the resistivity value is between 220 and $770 \Omega \mathrm{m}$, whereas at unsuccessful boreholes the lower parts of the drilled range have resistivity values higher than $770 \Omega \mathrm{m}$. Also, the thickness ratio of the weathered and semi-weathered layer in the unsuccessful boreholes is less than $1 / 3$, whereas in all successful boreholes the ration is higher than $1 / 2$. The difference between autochthon and allochthon layers was detected by heavy minerals content in the red eolian sand layer (Tupuito formation) that increased the chargeability value. The groundwater with a conductivity higher than $2000 \mu \mathrm{S} / \mathrm{cm}$ is linked to the white eolian sand. The surface extension of white eolian sand layer is small to be mapped; therefore, by
\end{abstract}

\footnotetext{
F. J. Chirindja

farisse.chirindja@tg.lth.se

Lunds Universitet, Lund, Sweden

Eduardo Mondlane Uninversity, Maputo, Mozambique

Ara Centro, Beira, Mozambique
}

mapping the eolian white sand formation and the use of ERT and enhanced with IP method would lower the failure rate.

Keywords Electrical resistivity tomography ·

Hydrogeology · Induced polarization · Margin basins

\section{Introduction}

The majority of people in Mozambique lives in rural areas and only $29 \%$ in rural areas have access to an improved source of drinking water (AMCOW 2012). In response, the Mozambique Government embarked on the Rural Water Point Installation Program (RWPIP) in the provinces of Nampula and Cabo Delgado in northern Mozambique. During a period of 3 years, a total of 600 wells were installed including all facilities and sanitation costing approximately US $\$ 200$ million (MCA 2013). The program had to deal with boreholes failing to supply fresh water. The failures are caused by very low yield in the crystalline basement areas as well as saline water in sedimentary formations located distant to today's coastal zones. An approach toward dealing with such reasons of failures will be presented in this paper.

The occurrence of groundwater in crystalline basement is controlled by the thickness of the weathered layer and fractures (MacDonald and Calowb 2008). However, it becomes complex when transgression/regression events form new aquifer systems on top of the basement along the continental margins. The basement aquifers in Africa have developed in Precambrian metamorphic and plutonic igneous rocks that occur in many Sub-Saharan countries (MacDonald and Calowb 2008) and are related to the various weathering-erosion cycles which have shaped the 
African continent (Clark 1985). Although these hard rock aquifers occur regionally, they are discontinuous and the thickness varies with the degree of weathering and exposure to processes of erosion (Wright 1992). Lateral variation in thickness is an important factor to the productivity of the wells (MacDonald and Calowb 2008). Continuity, thickness and preservation of the weathering profile of a productive basement aquifer determine the likelihood of success or failure of water drilling projects. It is therefore important to reconstruct the geological evolution of a particular area from the perspective of the potentials for the formation and preservation of aquifers.

Some ambiguity exists in the interpretation of vertical electric sounding (VES) results as for example, a low resistivity layer can be explained either by the presence of clay or the presence of saline water (Slater and Lesmes 2002)

The aim of this study is to reconstruct the aquifer formation in the study areas based on the results of geological and geophysical investigation. The obtained hydrogeological model would be used to explain the causes of borehole failures and suggest improved methodology to select drilling locations for future projects.

\section{Study area}

\section{The study area}

The study area is Mongicual district situated in the Eastern part of Nampula province of Mozambique, between Motomonho River to the North and Metomode River to the south, and bound by Meconta and Mugovolas districts to the West and the Indian Ocean to East (Fig. 1). The district is drained by Mongicual River where people go to fetch water. In this Mongicual River, the water dries out during the dry season when the groundwater level decreases. Wells will potentially provide water with improved chemical and bacteriological quality to people and provide water throughout the dry season.

Under the RWPIP, 40 boreholes were drilled in this district for ca 11,000 inhabitants which live widely scattered in family clans (Design Report 2010). The RWPIP designed that one borehole should supply water for approximately 500 inhabitants and have a water-yield of at least $900 \mathrm{l} / \mathrm{h}$ to be determined as sufficient for completion. A lower yield was defined as acceptable when less than 500 people in a community were served (Design Report 2010).

\section{Regional geology}

The study area is located at the transition of the Precambrian basement complex formed by Nampula and Monapo
Complexes and a marginal sedimentary basin (Lächelt 2004). Nampula Complex is described as a complex of migmatite-granitoid group of rocks (Lächelt 2004) that belongs to the Mozambique orogenetic units with ages of 1100-850 Ma. These rocks outcrop in form of Inselbergs that are small residual hills which stand in isolation above the general level of the surrounding erosional plains (Singhal and Gupta 2010). The Mesoproterozoic rocks form the basement of a relatively small sedimentary basin in the study area (Allan et al. 1990; Macey et al. 2007).

This marginal sedimentary basin is evolved between two major Mesozoic-Cenozoic basins, Rovuma Basin to the North and Mozambique Basin to the South (Salman and Abdula 1995). They are formed as a result of the breakup of Gondwana and the formation of the Indian Ocean at the end of Mesozoic (Salman and Abdula 1995; Macey et al. 2013). In the study area, the intrabasin is shallow with less than $50 \mathrm{~m}$ depth increasing toward the Indian Ocean (Macey et al. 2007). The basement is covered by the Pleistocene allochthon weathered reddish brown paleocoastal dune ridge (Tupuito formation) in an east-facing slope described by Macey et al. (2007) as an erosional feature or Pediment (Singhal and Gupta 2010). The sand dune (Tupuito formation) was deposited during the transgressions in the late Pleistocene and Holocene in a coastal environment. The red color is a result of oxidation of iron and other heavy minerals (Macey et al. 2007). Oxidation is a part of chemical weathering process going on in this formation which resulted in a heavy mineral deposit in Moma district (Macey et al. 2007). However, the decreasing with depth of $\mathrm{pH}$ and magnetic susceptibility values suggest that the fersiallitic pedogenesis and weathering is most intense within the upper part of the soil profile (Macey et al. 2007). The Tupuito formation is covered by eolian white sand dunes and quaternary alluvial sediments composed by gravel, sand and clay (Macey et al. 2007).

\section{Regional hydrogeology}

The hydrogeological map of Mozambique, scale 1:1,000,000 derived from Ferro and Bouman (1987), shows three different quaternary hydrogeological units above the basement (pEG) (Fig. 1). The pEG is covered by the paleocoastal dune $(\mathrm{QpE})$ constituted by fine to medium red sand, the eolian white sand (Qd) constituted by coarse to medium sand, and the alluvial clay and sand (Qal) (Ferro and Bouman 1987). Little is known about the fractured aquifers at a depth of $>50 \mathrm{~m}$. Fractured aquifers are all related to basement aquifers. According to Ferro and Bouman (1987), all Quaternary units are permeable and the yield measured from boreholes varies from 5000 to $10,000 \mathrm{l} / \mathrm{h}$, whereas the basement unit has low permeability and the yield is less than $3000 \mathrm{l} / \mathrm{h}$. 


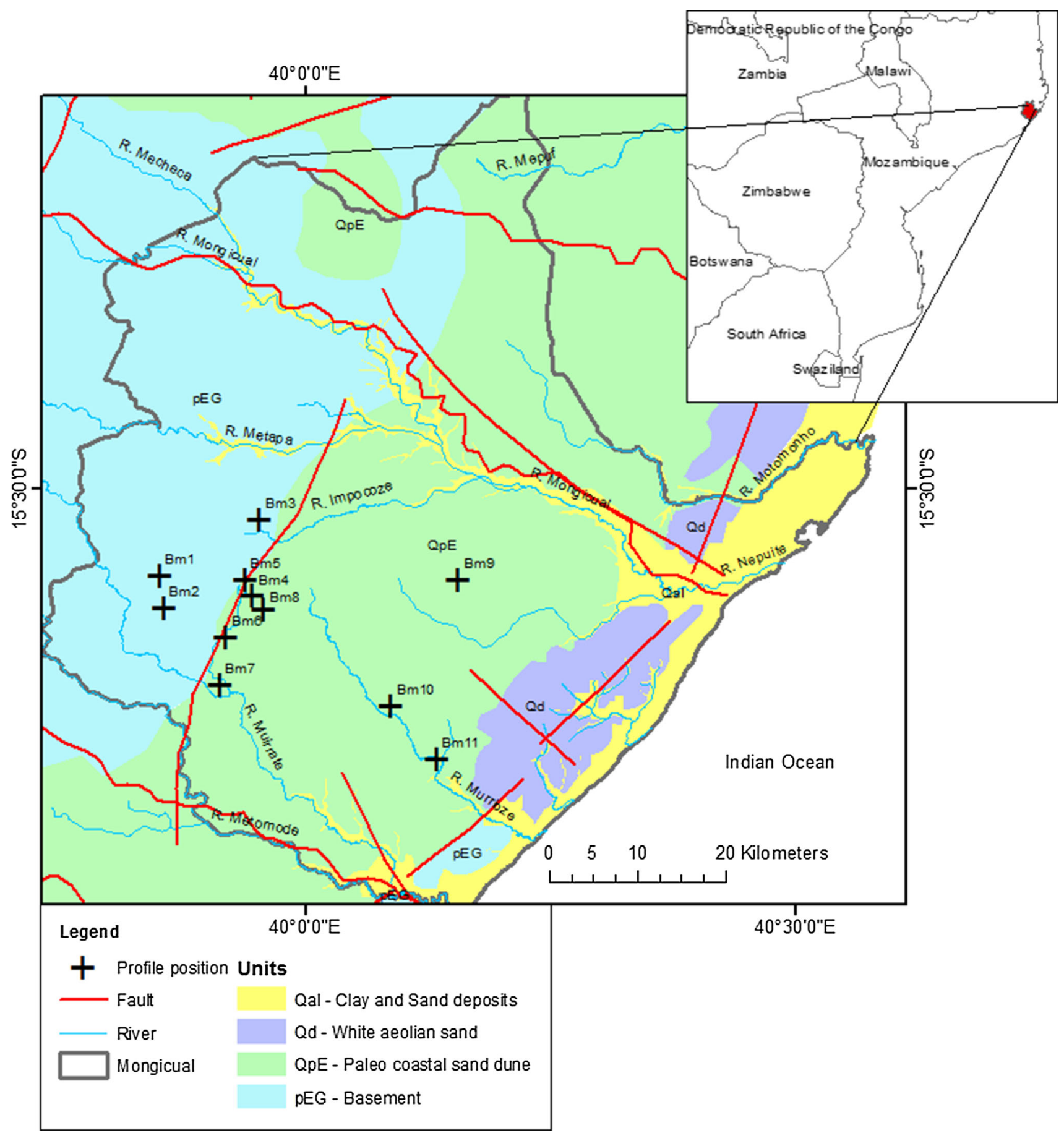

Fig. 1 Location of the research area (red color) and the hydrogeological map (adapted from Ferro and Bouman 1987) showing the positions of surveyed lines (Bm1-Bm11)

\section{Hydrogeological processes}

The hydrogeological setting of the study area is related to the evolution of sedimentary basins which are common in all East Africa. The evolution of these sedimentary basins was divided in two stages (Salman and Abdula 1995): (1)
Gondwana stage comprised a period between 300 and $157 \mathrm{Ma}$ ago (Late carboniferous to Middle Jurassic). This stage was characterized by the development of sedimentary basins within the single Gondwana continental mass. (2) Post-Gondwana stage beginning in Upper Jurassic $157 \mathrm{Ma}$ and continuing to the present. This stage was a period of an 
active breakup of Gondwana and the formation of continental margins of today's Indian Ocean.

Post-Gondwana stage was subdivided in three phases (Salman and Abdula 1995): (1) the breakup of Gondwana-during this period Gondwana split into two major blocks: West Gondwana (Africa and South America) and East Gondwana (Antarctica, India and Sri Lanka, Madagascar, Seychelles and Australia); (2) stabilization-comprised the stabilization of the East African continental margins accompanied by volcanic activities resulting in the deposition of thick volcanogenic and volcanogenic-sedimentary sequences; (3) neorifting-began 35 million years ago lasting till present.

In Oligocene, the African block rose, accompanied by marine regression. In the Miocene transgression the shallow-water marine environment was restored over a wide shelf. Active rifting of East Africa was also reflected along the continental margins. During Quaternary, the shallow-water shelf of the Miocene sea underwent regional uplifting and those sediments form presently outcrops on the coastal plains (Salman and Abdula 1995).

The Mesoproterozoic gneiss is the basement for the basin in the study area (Allan et al. 1990). The sedimentary cover is composed by eolian sand of different ages and fluvial deposits. The fluvial deposits of reworked gneiss in the West are composed of gravel sand and clay deposited in fluvial environment (Allan et al. 1990). The Valley of Mapane, Monotomo and Mongicual Rivers (Fig. 1) is well developed and cutting into Precambrian formations and therefore might be resting on a zone of weakness and being a river system that may have existed during Mesozoic.

Three hydrogeological units with different aquifer properties can be identified: the basement aquifer ( $\mathrm{pEG}$ ), red coastal dune ridge aquifer $(\mathrm{QpE})$ and white eolian sand aquifer (Qd). pEG underlays the study area with outcrops to the West and plunging eastwards. The permeability depends on the fracture density and the thickness of the weathered layer. The yield is less than $3000 \mathrm{l} / \mathrm{h}$ and may reach $5000 \mathrm{l} / \mathrm{h}$ in favorable zones (Ferro and Bouman 1987).

The QpE extends over the entire survey area and it is expected to be a more productive aquifer because the permeability and porosity is likely to be high (Ferro and Bouman 1987). In such a case, the yield will depend on the thickness of this formation.

Qd consists of discontinuous units (lenses) controlled by the altitude which can be explained by the ongoing uplifting of Nampula block (Macey et al. 2007) as well as by the climate-controlled sea-level changes. The expected permeability and porosity is high and so the yield.

\section{Rock decomposition and expected geophysical signal}

When rocks are exposed to the earth atmosphere, weathering takes place. As a result, weathered and semi-weathered layers known as regolith (Kumar et al. 2016; Wright 1992) form on top of the bedrock (Fig. 2). The regolith is composed by duricrust, saprolite and saprock (Fig. 2) (Acworth 1987). The duricrust is a near surface layer composed of re-concentrated and undissolved minerals of $\mathrm{Fe}, \mathrm{Al}$ and $\mathrm{Si}$. Saprolite is composed of weathered products of the bedrock and precipitation of leached products from duricrust. At the base of the saprolite lies the saprock which is composed of large blocks of unweathered bedrock surrounded by a matrix of slightly weathered materials (Acworth 1987). The thickness and degree of weathered material are closely related to cycles of relative tectonic stability and the type of the primary rocks (Sharp 2014). In former Gondwana areas which had remained stable since Mesoproterozoic the regolith can extend to depths as great as $90 \mathrm{~m}$ for granite and gneiss (Strahler 1971). In the classical profile, the thickness of the weathered layer is $1 / 3-1 / 2$ of the semi-weathered zone (Sharp 2014). A

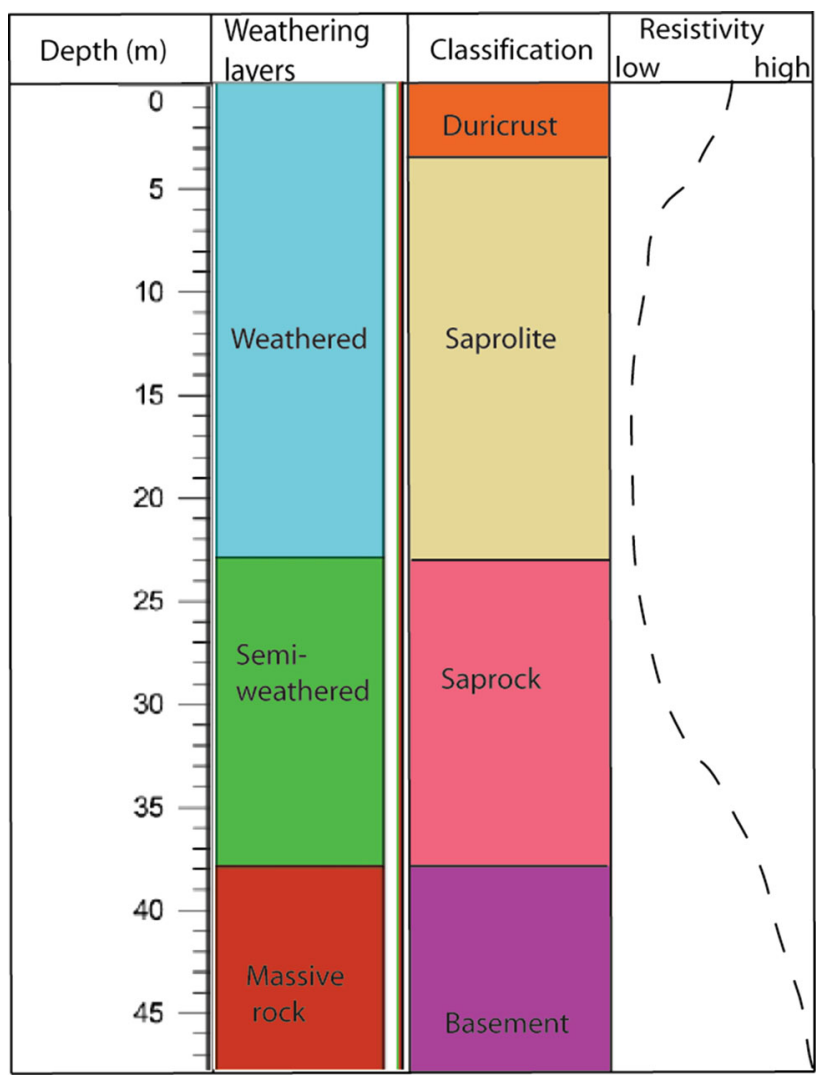

Fig. 2 An example of schematic weathering profile and tentative geophysical resistivity model of each zone. Adapted from Acworth (1987) and Kumar et al. (2016) 
change in this ratio is attributed to the removal of the weathered layer by erosion or the addition of material by allochthon sediments.

According to Acworth (1987), soluble minerals are leached from the weathered layer (duricrust and saprolite) downward. The thickness of the weathered layer varies with the degree of weathering and it has high porosity and permeability. The semi-weathered layer (saprock) is characterized by an accumulation of secondary minerals formed in situ by ion exchange (smaller atoms by larger) and hydration (complexation) leached from the weathered layer. Therefore, the permeability and porosity will decrease in the uppermost part of this layer. The bottom of the semi-weathered layer is characterized by laminated fractures and fissures; hence, the permeability will increase and the porosity decreases.

Water percolating through the weathered material will leach all soluble chemical elements and moves clay fine particles present from the upper near surface and precipitate when the chemical conditions change. This process takes actively place at the boundary of the phreatic-vadose zone. As a result of this leaching and mineral precipitation, the initially favorable hydraulic conditions for an aquifer in the laminated fissure zone are lost (Sharp 2014).

The expected variation of resistivity values is presented in Fig. 2. High resistivity values are expected at the surface. Dry and unconsolidated coarse sediments have high permeability and porosity which yield a high resistivity value (Acworth 1987; Palacky 1988). The resistivity value decreases downward from the surface to saprolite due to compaction of the sediments that decreases the porosity, while the clay and water content increases. The resistivity values will increase again when moving from the saprolite layer to the basement due to reduction of weathered material. In the basement, the primary porosity and permeability are low and groundwater is found only in fractures. A reduced value of resistivity compared to the massive rock is expected when a fracture is struck.

\section{Materials and methods of data acquisition}

\section{Boreholes: ground control points}

The choice of drilling sites within RWPIP was based on VES results. In total 56 borehole were drilled from which $71 \%$ had enough yield for village water supply and were equipped as water wells. For each drilled borehole under the RWPIP, a report with information about the drilling rate, geological logging, well completion and water quality exists. The authors collected the reports of the 11 wells used as ground control sites to validate the ERT models.
The center point of each ERT profiles was set to coincide with borehole position.

The choice to survey these boreholes was based on the fact that $\mathrm{Bm} 1, \mathrm{Bm} 2$ and $\mathrm{Bm} 3$ are located in basement and $\mathrm{Bm} 4, \mathrm{Bm} 5, \mathrm{Bm} 6, \mathrm{Bm} 7, \mathrm{Bm} 8, \mathrm{Bm} 9, \mathrm{Bm} 10$ and $\mathrm{Bm} 11$ are located in the basin filled with continental and marine sediments. Bm1 and Bm10 were abandoned, as negative well, because no water was found up to the depth defined by the drilling contract. Unfortunately as it often happens, log reports were not archived and water quality parameters not documented for the dry boreholes.

\section{Field measurements and data analysis}

In June 2014, combined ERT and IP measurements were made at drilling sites in 11 communities. Two perpendicular lines were measured at each site. The profiles were made perpendicular to describe the variation in three dimensions. At Bm4 only one profile was taken because the terrain was too rough to set the second profile. The lengths of each survey profile were $400 \mathrm{~m}$ with a depth penetration of around $70 \mathrm{~m}$.

The used Terrameter LS measures both resistivity and chargeability. The instrument was connected to electrode cables with $5 \mathrm{~m}$ spacing between the electrodes. In total 81 electrodes were used which make a full spread of $400 \mathrm{~m}$. The current is passed into the ground, and the potential is measured up to 12 channels which speeds up the measurements. The data were collected as 2D resistivity tomography using the roll-along system (Dahlin 2001). The survey was measured using a multiple gradient array which has an advantage in fast data acquisition with good signal to noise ratio, in combination with a good ability to resolve geological structure (Dahlin 2001; Dahlin and Zhou 2006).

The data quality was checked by visual observation of the pseudosection in Erigraph software and edited in Res2Dinv. After field data quality check, the data were inverted and produced 2D models using the software Res2Dinv. The model is an idealized mathematical representation of the measured subsurface (Reynolds 2011). Each model has information of both IP and resistivity. For the interpretation, the IP results were presented as normalized chargeability (MN).

\section{Results and interpretation}

\section{Surface geology}

Two sand formations (Fig. 3) were identified in the field and are also shown on the national level hydrogeological map. A white eolian Quaternary (Qd) sand formation 

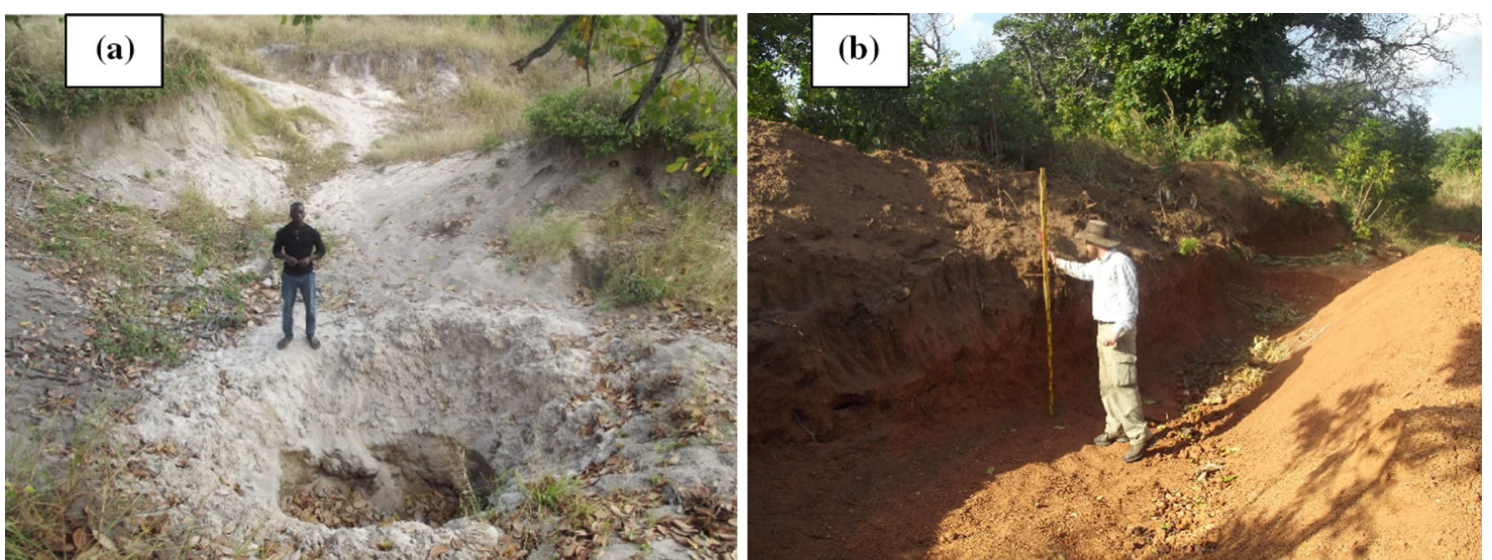

Fig. 3 Two different sand layers occur in the study area. a White sand close to Bm3 and $\mathbf{b}$ red sand close to $\mathrm{Bm} 7$

(Fig. 3a) was picked up in some areas at the scale of the national geological and hydrogeological maps while left out in others. Being the only map source available at this time, this cartographic principle (scale dependent simplification of map contents) probably caused the misinterpretation of previous geophysical results at local scale by the field team of RWPIP. A reddish sand formation (Fig. 3b) which is common in the study area is indicated in Fig. 1 as fossil dune of Tupuito formation (QpE).

\section{Geological log}

The comparison of the weathering profile thickness of surveyed sites based on the geological borehole logging report is presented in Table 1. The white sand layer is only present at $\mathrm{Bm} 3, \mathrm{Bm} 6, \mathrm{Bm} 8$ and $\mathrm{Bm} 9$ with a thickness varying from 7 to $25 \mathrm{~m}$. The thickness of the weathered layer varies from $6 \mathrm{~m}$ at $\mathrm{Bm} 1$ and $\mathrm{Bm} 9$ to $29 \mathrm{~m}$ at $\mathrm{Bm} 11$ and the thickness of semi-weathered layer varies from $7 \mathrm{~m}$ at $\mathrm{Bm} 9$ to $31 \mathrm{~m}$ at $\mathrm{Bm} 1$ (Table 1).
The weathering profiles shown in bolded values (Table 1) had additional sediments placed on top of the weathered basement. The additional sediments are eolian white sand and red coastal dune ridge (Fig. 1). The italicized values indicates the boreholes with WL/SWL ratio less than $1 / 3$ which is caused by erosion of the top weathered layer. It coincides also with the unsuccessful boreholes except $\mathrm{Bm} 2$.

\section{Interpretation of geological and drill log}

The drilling report includes the description of the cuts from the drilling on which the interpretation of the drilling log was based. The cuts were described in terms of color, texture and geological material. The spatial variation of the described geology was made by correlating boreholes in three different profiles.

Figure 4 shows the correlation of the surveyed boreholes in three different profiles $\mathrm{AB}, \mathrm{CD}$ and $\mathrm{EF}$ directed $\mathrm{W}-\mathrm{E}, \mathrm{N}-\mathrm{S}$ and NW-SE, respectively. The depth to the

Table 1 Thickness of different layers from borehole logging information and its relationship with the weathering profile of Fig. 2

\begin{tabular}{|c|c|c|c|c|c|c|c|c|c|c|c|}
\hline \multirow[t]{2}{*}{ Material } & \multicolumn{11}{|c|}{ Thickness (m) } \\
\hline & $\mathrm{Bm} 1$ & $\mathrm{Bm} 2$ & $\mathrm{Bm} 3$ & $\mathrm{Bm} 4$ & Bm5 & Bm6 & $\mathrm{Bm} 7$ & $\mathrm{Bm} 8$ & Bm9 & $\mathrm{Bm} 10$ & Bm11 \\
\hline Sand layer & 0 & 0 & 9 & 0 & 0 & 7 & 0 & 25 & 21 & 0 & 0 \\
\hline Weathered layer & 6 & 17 & 12 & 24 & 25 & 12 & 12 & 10 & 6 & 7 & 29 \\
\hline Semi-weathered layer & 31 & 25 & 9 & 9 & 12 & 9 & 8 & 15 & 7 & 28 & 16 \\
\hline Basement & 23 & 3 & 3 & $\mathbf{0}$ & $\mathbf{0}$ & 15 & 25 & 2 & 11 & 10 & 5 \\
\hline Total drilled depth & 60 & 45 & 33 & 33 & 37 & 43 & 45 & 52 & 45 & 45 & 50 \\
\hline Bottom elevation (masl) & 90 & 90 & 72 & 97 & 93 & 57 & 30 & 73 & 85 & 25 & 10 \\
\hline Ratio WL/SWL & 0.19 & 0.68 & 1.33 & 2.63 & 2.12 & 1.33 & 1.50 & 0.66 & 0.86 & 0.25 & 1.81 \\
\hline Yield (1/h) & - & 1200 & 1400 & 2800 & 800 & 1000 & 1500 & 800 & 1200 & - & 1100 \\
\hline
\end{tabular}

Italics partially disturbed (removal/replacement with allochthon material), bold allochthon cover and bolditalics marine sediments. WL stands for weathered layer, and SWL stands for semi-weathered layer 


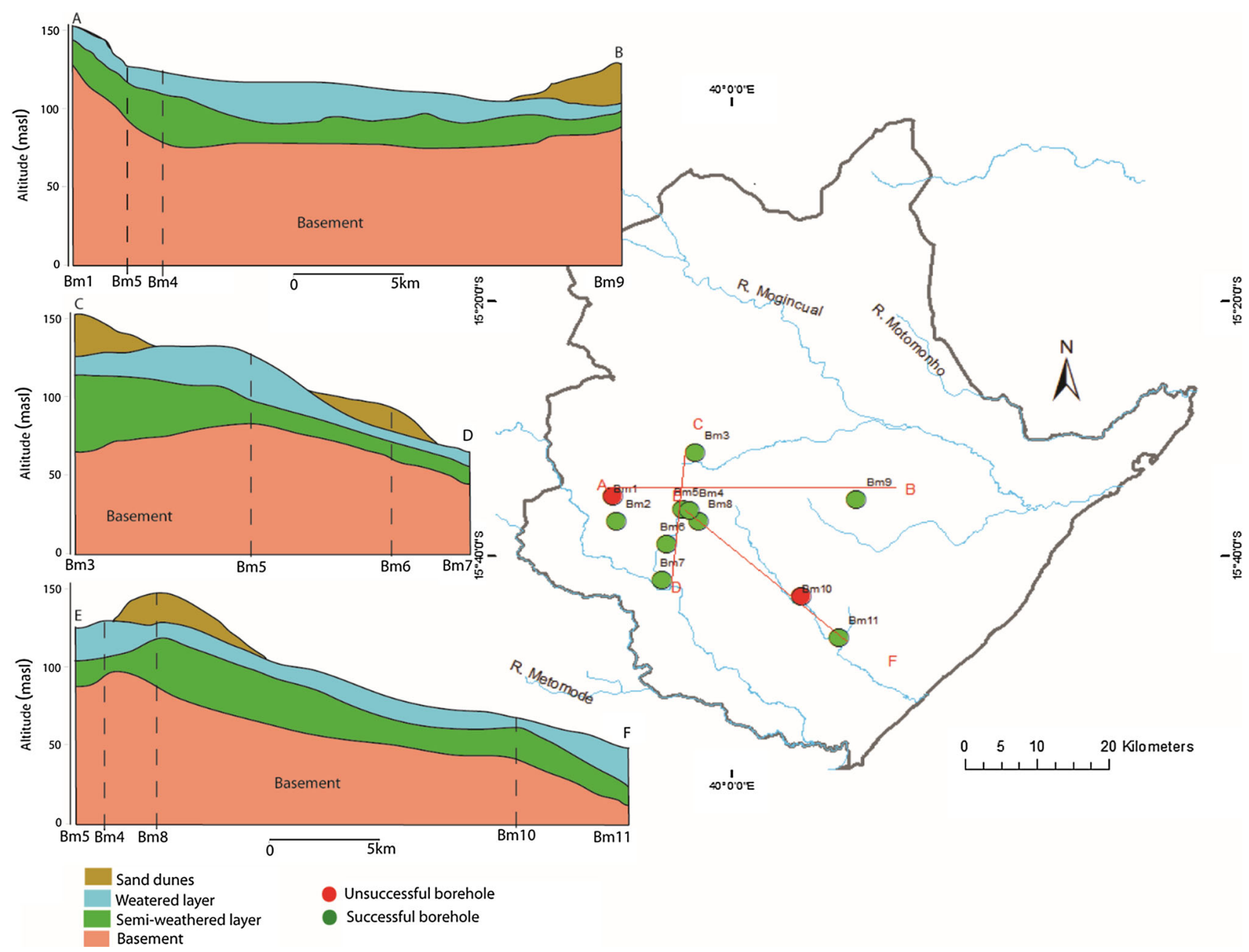

Fig. 4 Geological sections based on borehole logging from the ground truth points, and a map of the location of the boreholes and cross sections

basement is generally increasing eastward as seen in the profiles $\mathrm{AB}$ and EF (Fig. 4). Weathered and semi-weathered layers are continuous layers that are present in all boreholes. However, the thickness (Table 1) varies from borehole to borehole. The eolian white sand formation is a discontinuous layer that occurs on top of the weathered and semi-weathered layers. It mainly occurs above the 100 masl contour line.

\section{Surface geophysics}

Figure 5 shows all inverted ERT models and the position of the water wells that were used as ground truth. The L1 inversion method has been used as it gives a strong contrast in resistivity mainly between soil and fresh rock. The inverted models have a low residual error ranging from 1.0 to $2.4 \%$. The perpendicular ERT models reveal similar variation in resistivity and thickness of the layers.

In the bottom of the models, there is a resistivity layer with resistivity value between $220 \Omega \mathrm{m}$ and more than
$5000 \Omega \mathrm{m}$ which was interpreted as the basement. The strong lateral variation of the resistivity values within the basement is an indication of variation in depth of the weathered zone and degree of fracturing. This variation must be expected to have a profound impact on the occurrence of groundwater due to the variation in fracture density and secondary porosity.

The basement is overlain by a layer with a resistivity value in the range of $10-120 \Omega \mathrm{m}$ indicating a weathered zone. The thickness of this layer varies from $5 \mathrm{~m}$ in $\mathrm{Bm} 6$ to more than $60 \mathrm{~m}$ in some positions of $\mathrm{Bm} 4$ and $\mathrm{Bm} 9$ profiles. The near surface layer in the models shows high resistivity values ranging from 120 to $1400 \Omega \mathrm{m}$ indicating unconsolidated and dry sediments. The thickness of this layer is less than $15 \mathrm{~m}$.

The target layer for water abstraction, as demonstrated by depth of the drilled boreholes (Table 1), has resistivity value in range of $220-770 \Omega \mathrm{m}$. The borehole $\mathrm{Bm} 4$ with the maximum yield of $2800 \mathrm{l} / \mathrm{h}$ (Table 1 ) ends in a resistivity layer of $220-420 \Omega \mathrm{m}$. Also for Bm2 and Bm9, the drilled 

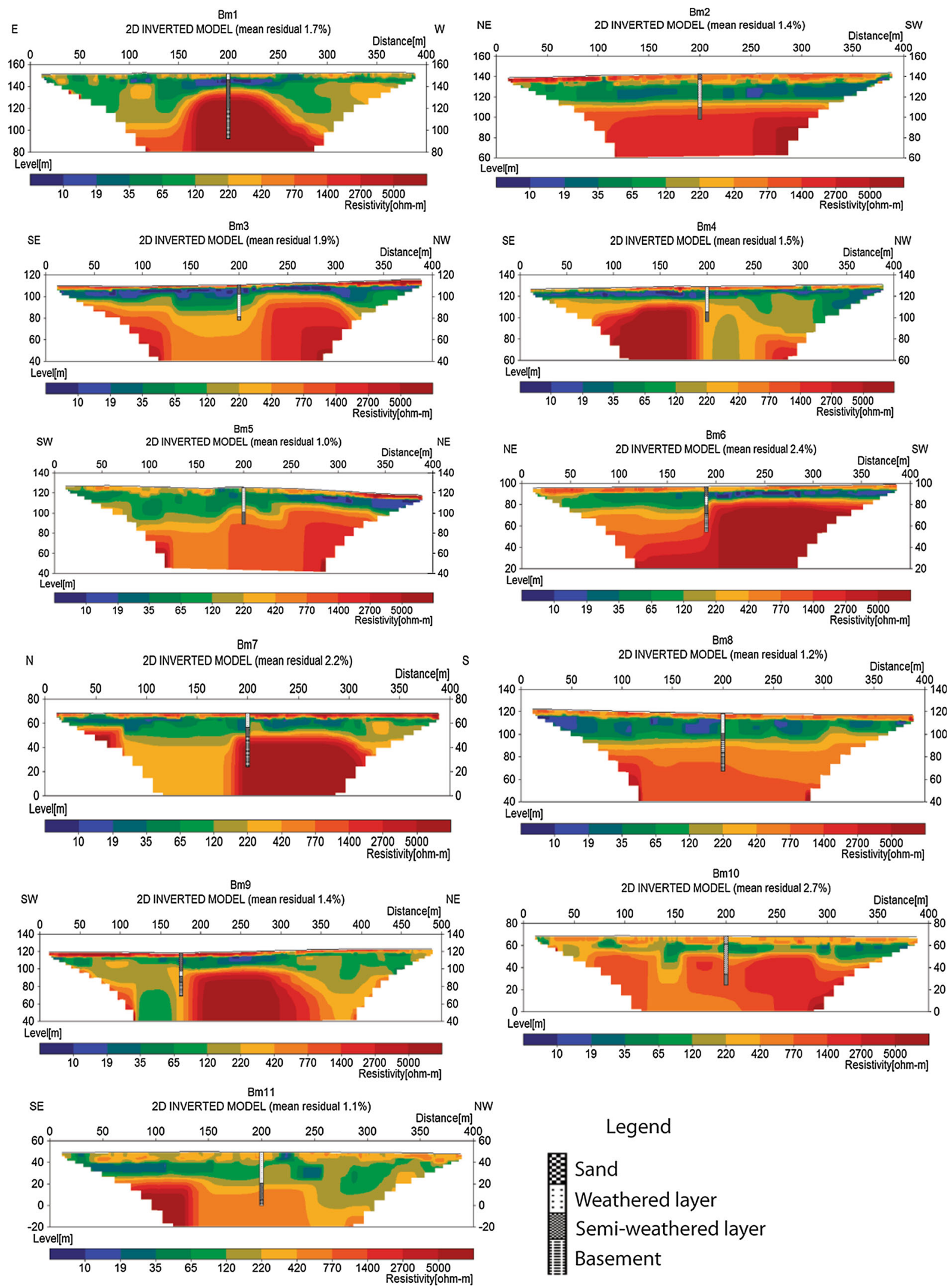

Legend

Sand

Weathered layer

Semi-weathered layer

Basement

Fig. 5 Resulting models of ERT including the position of the wells 
borehole ends in the same resistivity range. Borehole $\mathrm{Bm} 1$ which ends in higher resistivity turned out unsuccessful, whereas borehole $\mathrm{Bm} 7$ has a yield of $1500 \mathrm{l} / \mathrm{h}$. The latter may be explained by the increased ratio WL/SWL at Bm7 (Table 1).

\section{Normalized chargeability results}

Three models representing normalized chargeability values of the pEG, QpE and Qd areas (Fig. 1) are shown in Fig. 6 where the models can be divided into three parts with high, intermediate and lower values of normalized chargeability. The mean residual error is between 1.5 and $3.6 \%$ which is an indication of acceptable inverted results.

From the bottom of the inverted IP models, the normalized chargeability is low $(<0.025 \mathrm{mS} / \mathrm{m})$ where basement has been documented from the drilling. Immediately above the parts with shallow basement there is a layer with high normalized chargeability value $(0.025$ to $<1 \mathrm{mS} / \mathrm{m})$. The thin shallowest layer has normalized chargeability of $0.016-0.063 \mathrm{mS} / \mathrm{m}$, classified as dry sand in the drilling reports, which is probably not so well sorted because it is in situ weathered.

In the areas outside the shallow basement occurrences, the normalized chargeability is generally intermediate, with values in the range $0.04-0.16 \mathrm{mS} / \mathrm{m}$. This can be interpreted as being related to the higher degree of deep

(a)
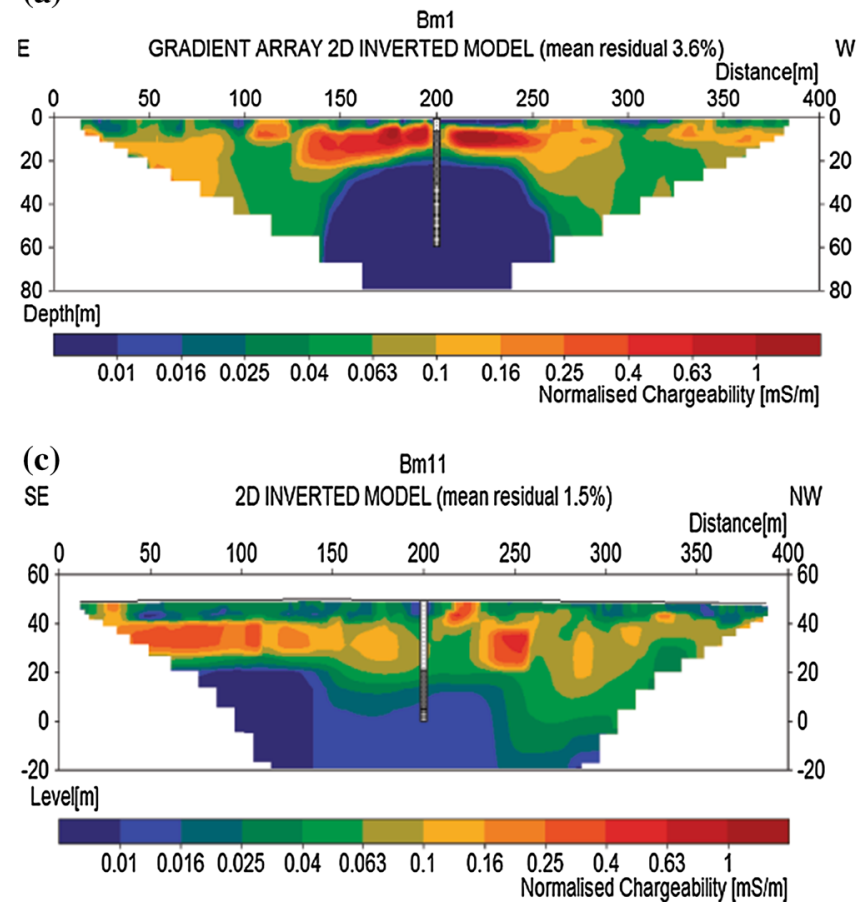

weathering and associated leaching of clay minerals from the shallow parts of the formation.

The high chargeability layer has a more discontinuous character at $\mathrm{Bm} 9$, but the reason for this is not known. Here the shallowest layer has a normalized chargeability is lower than for the other lines, being less than $0.01 \mathrm{mS} / \mathrm{m}$, which may be interpreted as well sorted dry sand.

The high normalized chargeability layers and low resistivity value in profile $\mathrm{Bm} 1$ and $\mathrm{Bm} 11$ suggest the overburden may contain organic material, precipitated minerals or clay content. As indicated by the borehole documentation, the clay layer coincides with this zone (Fig. 6). On the other hand, it was expected that for Bm9 the normalized chargeability would be lower due to the presence of a thick layer of sand. The high chargeability appears in this case to be caused by the presence of heavy mineral sand, in which it is likely that metal precipitation products that make the formation act as a disseminated ore. The high electrical conductivity of the groundwater may in turn be caused by dissolution from the mineral content of the soil.

\section{Water quality}

Basic water quality indicators were measured in all boreholes except the dry ones (Bm1 and Bm9). The physical parameters $\mathrm{pH}$, conductivity and temperature were

Fig. 6 Inverted IP models showing the normalized chargeability: a Bm1, b Bm9 and c Bm11 
Table 2 Result of measurement of physical parameters of groundwater quality at different boreholes $(\mathrm{pH}$, temperature and conductivity)

\begin{tabular}{lllc}
\hline Borehole & PH & Temp $\left({ }^{\circ} \mathrm{C}\right)$ & Cond. $(\mu \mathrm{S} / \mathrm{cm})$ \\
\hline Bm2 & 6.44 & 27 & 1444 \\
Bm3 & 6.87 & 28.6 & 2600 \\
Bm4 & 6.4 & 28.5 & 1278 \\
Bm5 & 6.25 & 27.9 & 595 \\
Bm6 & 6.62 & 25.8 & 2240 \\
Bm7 & 6.84 & 27 & 382 \\
Bm8 & 6.43 & 28.5 & 360 \\
Bm9 & 6.41 & 28.5 & 2820 \\
Bm11 & 5.97 & 30 & 470 \\
\hline
\end{tabular}

measured using the ExStik EC510 equipment and the results are presented in Table 2.

The $\mathrm{pH}$ of water at $\mathrm{Bm} 3$ and $\mathrm{Bm} 7$ is in the range of 6.5-8.5 which is the Mozambican standard guideline for potable water. For all other borehole, the measured value of $\mathrm{pH}$ is below the standard range which indicates that the water is acidic. The standard value of conductivity for domestic water is below $2000 \mu \mathrm{S} / \mathrm{cm}$ (Portal do Governo 2016). This value is exceeded at $\mathrm{Bm} 3$ and Bm6 (Table 2).

\section{Discussion}

\section{Combined interpretation of geophysical and geological data}

The study area was affected by eustatic Mesozoic/Cenozoic sea-level fluctuations as result of neorifting (Salman and Abdula 1995) characterized by uplifting of Nampula block and formation of a shallow margin sedimentary basin. The Miocene regression wiped out the weathered horizons (Allan et al. 1990; Macey et al. 2007) and continental sediments (eolian) were deposited directly on top of the plane surface of the basement (Macey et al. 2007). The marine sediments were deposited on top of the continental sediments in the following Pleistocene transgression. Adding information of the borehole geological logging report and the inverted ERT models, the reconstruction of the geological history can be summarized in five different events: (1) pre-Gondwana supercontinent; (2) breakup of Gondwana; (3) neorifting event; (4) Cenozoic sand dunes formation (Tupuito formation); (5) uplifting of the African block and deposition of eolian white sand in Pleistocene.

The weathered layer of Mesoproterozoic gneiss (Fig. 7a) was removed during the transgression caused by breakup of Gondwana supercontinent during the
Jurassic. As consequence pediments were formed (Fig. 7b). When the sea level was lowered due to rifting $35 \mathrm{Ma}$ ago, the pediments were covered by coastal sand dunes (red sand ridge in Fig. 7c). The cycle of transgression/regression which occurred during Tertiary (Salman and Abdula 1995) resulted in deposition of coastal sand dunes (Macey et al. 2007). This deposit underwent chemical weathering (oxidation) resulting in red sand locally known as Tupuito formation (Lächelt 2004; Macey et al. 2007). This paleo-sand dune ridge forms a steep seaward slope, and it has an erosional feature been covered locally by eolian sand or thin wind redistributed sand cover (Fig. 7e).

The inverted ERT models interpreted together with borehole logging information have improved the geological understanding of subsurface in the study. All resistivity layers have irregular thickness most likely caused by erosion (Bm1 in Fig. 5) and deposition processes (Bm3, Bm4, Bm5, Bm6, Bm7, Bm8; $\mathrm{Bm} 9$ and $\mathrm{Bm} 11$ in Fig. 5). In Bm1 and Bm10, the thickness ratio of the weathered layer to semi-weathered layer is less than $1 / 3$ (see Table 1) indicating that the weathered layer was eroded (Sharp 2014). The additional geological material on top of the weathering layer, where the ratio is higher than $1 / 2$, is the red sand dunes and white eolian sand (Bm3, Bm6, Bm8 and Bm9).

The degree of fractures in the basement is indicated by the variability of the resistivity values and the yield. The resistivity value of the basement at $\mathrm{Bm} 4$ (Fig. 5) is in a range of 220 to $>5000 \Omega \mathrm{m}$ with a yield of $2800 \mathrm{l} / \mathrm{h}$. At $\mathrm{Bm} 3, \mathrm{Bm} 5$ and $\mathrm{Bm} 9$ (Fig. 5), the resistivity value is in the same range as in Bm4 but with yields much less than 2800 l/h (Table 1). According to Acworth (1987), a higher yield would be achieved by increasing the depth of the borehole by fully penetrating the fractured zone.

\section{Aquifers of the study area}

The inverted ERT models gave indication of layers with similar properties; however, the geological material might not be the same. There are differences in deposition environment or origin which can be seen in the geological borehole logging and the description of surface geology.

The pEG limited potential for groundwater extraction was confirmed by unsuccessful boreholes at $\mathrm{Bm} 1$ and Bm10. Boreholes Bm1and Bm10 were dry because of the nearly absent weathered layer. The WL/SWD ratio at both sites is less than $1 / 3$ (Table 1 ) which is an indication that the weathered layer was eroded. However, when the fractured zone is hit indicated by decreasing in resistivity as in $\mathrm{Bm} 2$ and $\mathrm{Bm} 7$ the borehole yield can reach 1200-1500 1/h. 
Fig. 7 Profiles with W-E orientation showing five different phases of the geological evolution as result of sea-level fluctuation.

a Weathering of the basement during pre-Gondwana breakup. b Breakup of Gondwana. c Regression and preposition coastal dunes. d Marine transgression and sedimentation and $\mathbf{e}$ ongoing uplifting of African block and deposition of eolian white sand

\section{I - Pre-Gondwana}

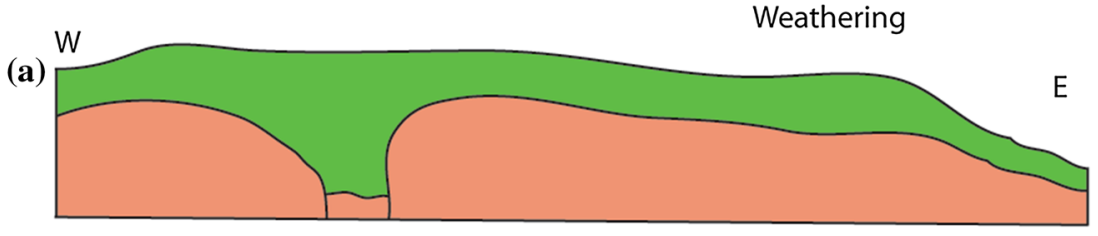

II - Break-up of Gondwana

(b)

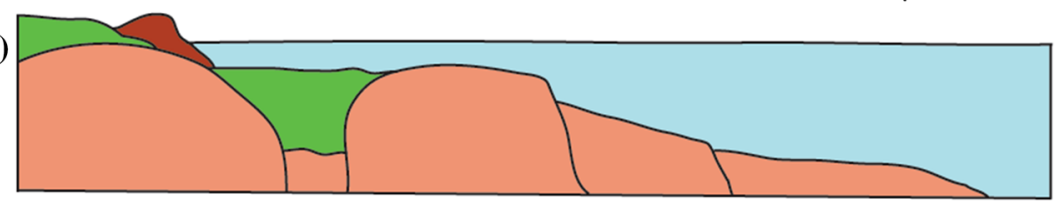

III - Neorifting

(c)

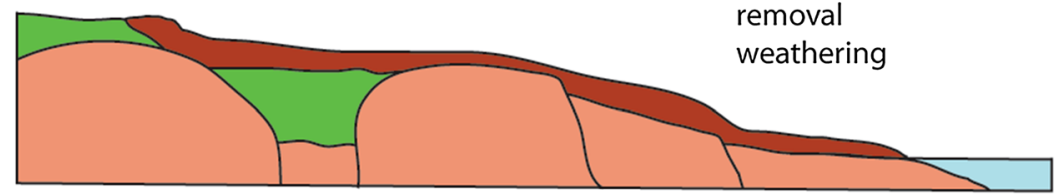

IV - 120000 years

(d)

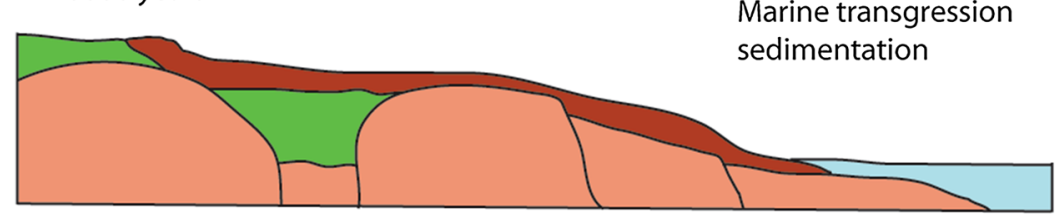

V - Uplifting of Africa block

(e)

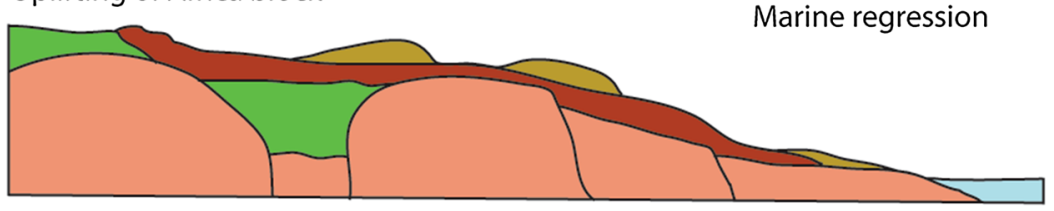

Basement $\_$Weathered layer $\square$ Red sand ridge $\square$ White sand dunes

Ocean
Also, when the layer with resistivity value in range of $220-420 \Omega \mathrm{m}$ is hit, the obtained yield is high (see Bm3, $\mathrm{Bm} 4$ and Bm9 in Fig. 5). The more productive well is $\mathrm{Bm} 4$ yielding $2800 \mathrm{l} / \mathrm{h}$ (Table 1) where the $\mathrm{pEG}$ is covered by QpE. The thickness of QpE varies following the basement shape. The permeability of QpE is highly influenced by ongoing weathering process where the fine material has been leached reducing the permeability toward depth. The QpE is partially covered by Pleistocene/Holocene white sand dune with thickness varying from 9 to $25 \mathrm{~m}$. Macey et al. (2007) includes the eolian colluvium to this Qd. This cover layer was observed in $\mathrm{Bm} 3, \mathrm{Bm} 6, \mathrm{Bm} 8$ and $\mathrm{Bm} 9$. As the layer is thin, the drilling continued reaching the QpE and $\mathrm{pEG}$. An intercommunication between these three units is likely and causing a mixing in water and probably a leaky aquifer response. The mixing also occurs during the infiltration of the rain water (recharge). The aquifers are recharged locally during the rainy season from November to March (Ferro and Bouman 1987).

\section{Interpretation of water quality of found aquifers}

The few available data for groundwater quality indicate two different types of water. A low and high mineralized water. The intermediate values could be an indication that the different aquifers are interconnected. Although the $\mathrm{pH}$ value is below the standard range for drinking water, the obtained values are also found in groundwater of similar geological environments (Singhal and Gupta 2010). This range of $\mathrm{pH}$ does not indicate recent saltwater intrusions or recent exchange with ocean water. It indicates, however, the exchange with rain water.

The IP measurement at Bm9 (Fig. 6) shows the effect of mineralized water. When one measures the resistivity by using VES, the low value usually is related to clay content as expected in a weathering profile (Acworth 1987). At $\mathrm{Bm} 1$ and $\mathrm{Bm} 11$, the increase in normalized chargeability in the shallow parts is explained by the presence of clay, as Slater and Lesmes (2002) demonstrated, where low 
resistivity values correspond with high normalized chargeability can be considered as areas with the presence of clayey sediments. However, at $\mathrm{Bm} 9$ the clay is not expected (as seen in Table 1); therefore, the increase in normalized chargeability can probably be explained by the presence of heavy minerals and oxidized iron. The presence of this geological material can also affect the mineralization of the groundwater.

\section{Groundwater management in Mongicual district}

A deep understanding and interpretation of hydrogeological processes which led to the formation of the three types of aquifers in the study area is important to understand how the aquifers can be utilized and managed. The extraction of water at the boreholes in the basement will use first groundwater stored in the fissured layer of the basement which will trigger a retarded response of vertical flows from $\mathrm{QpE}$ or $\mathrm{Qd}$, where present. Therefore, the water quality and quantity of these two aquifers will affect the well functions. It is important to map carefully the white eolian sand formation to prevent the contamination from the groundwater with elevated electric conductivity values as seen in Borehole Bm3, Bm6 and Bm9 (Table 2).

Because the sand and the weathered layer are highly permeable, the rain water will infiltrate and recharge the aquifers easily. However, with increasing population and semi-urbanization the infiltration area will reduce due to the sealing of the ground and less water will reach the aquifers.

As all rivers dry out during the dry season, the population currently relies on groundwater for a continuous water supply and therefore, it is important to protect the fragile aquifer systems through good management.

\section{Uncertainties}

Geological logging of the drill cuttings has its drawbacks, when using rotary percussion with air lifting method. Finer particle compounds may be underestimated or not documented. The depths positioning of lithological breaks will be smudged. In addition, the interpretation was neither made by a geologist nor on complete drill cores in the RWPIP drilling program and therefore it occurs that weathered gneiss is mistaken as coarse sand or pebbles and vice versa. Experts were called in only, when problems had hit. This means that the uncertainty of the borehole data is significant and should be taken into account in the geological interpretation. Had these interpretations been made by a trained geologist their validity would have been less questionable. It would also have made it easier to validate the ERT measurements with actual geological data.

\section{Conclusions}

The tendency in large-scale national drilling programs is to deploy a geophysical technique as a stand-alone method; normally using the VES 1D approach to identify suitable sites for water boreholes has proven to be insufficient. This investigation demonstrated that the boreholes when placed above or on the edge of a high resistivity zone with the ratio of weathered and semiweathered layer less than $1 / 3$ are likely to be unsuccessful. Also the yield of some borehole would have been increased if drilled in locations with more fractured rock and deep weathering. The findings suggest that such a faulty placement could have been avoided, if an ERT survey had been made instead of VES since there would have been more comprehensive information on the $3 \mathrm{D}$ character of the geology to make hydrogeological interpretations from. This is equally important in order to understand the geological context and hydrogeological processes which have shaped the area resulting in the formation or destruction of aquifers in order to interpret the geophysical results correctly.

Combining this understanding with the combination of ERT and IP would likely lower the rate of borehole failure and more boreholes could have been drilled from the same budget. Instead of drilling boreholes in areas identified as having poor conditions for hosting aquifers, initiative of rainwater harvesting and surface water management could be prioritized.

The basement, paleo-sand dune ridges and eolian white sand dunes formations are the three hydrogeological units in Mongicual district. They are recharged during the rainy season. Therefore, they are sensitive to climate change and also to human activities on the surface. The increasing population and semi-urbanization will reduce the infiltration area and, as consequence, deplete the groundwater.

Acknowledgements We would like to thank Cowater International Inc. and Solomon Lda for technical and logistical help for supporting this survey in the Nampula province. We also would like to thank B. Andersson, T. Björkström and Eduardo Mondlane staff for all kinds of support during the survey. Furthermore we gratefully acknowledge that Sida has funded the study as part of the bilateral cooperation framework between Eduardo Mondlane University (Mozambique) and Lund University (Sweden).

Open Access This article is distributed under the terms of the Creative Commons Attribution 4.0 International License (http://crea tivecommons.org/licenses/by/4.0/), which permits unrestricted use, distribution, and reproduction in any medium, provided you give appropriate credit to the original author(s) and the source, provide a link to the Creative Commons license, and indicate if changes were made. 


\section{References}

Acworth RI (1987) The development of crystalline basement aquifers in a tropical environment. Q J Eng Geol 20:265-272

Allan E, Nairn M, Lerch I, James E (1990) Geology, basin analysis, and hydrocarbon potential of Mozambique and Mozambique channel. Earth Sci Rev 30:81-124

AMCOW (2012) Water supply and sanitation in Mozambiqueturning finance into services for 2015 and beyond-an AMCOW Country Status Overview

Clark L (1985) Groundwater abstraction from basement complex areas in Africa. Q J Eng Geol 18:25-34

Dahlin T (2001) The development of DC resistivity imaging techniques. J Comput Geosci 27:1019-1029

Dahlin T, Zhou B (2006) Multiple-gradient array measurements for multichannel 2D resistivity imaging. Near Surf Geophys 4:113-123

Design Report (2010) Internal report, prepared by: Cowater Inc and Salomon Lda. Submitted to: Millenium Challenge AccountMozambique and the National Directorate of Water/Rural Water Department. Unpublished report

Ferro BPA, Bouman D (1987) Explanatory notes of the hydrogeological map of Mozambique, scale 1:1,000,000. Project of the hydrogeological map of Mozambique. National Directorate of Water Affairs, Mozambique

Kumar D, Mondal S, Nandam Harimi P, Soma Sekhar BMV, Sem MK (2016) Two-dimensional electrical resistivity tomography (ERT) and time-domain-induced polarization (TSIP) study in hard rock for groundwater investigation: a case study at Choutuppal Telangana, India. Arab J Geosci 9:355

Lächelt R (2004) Geology and mineral resources of Mozambique. Direccao Nacional de Geologica Moçambique, Maputo. ISBN 1-919908-52-8

MacDonald A, Calowb RC (2008) Developing groundwater for secure rural water supplies in Africa. Desalination 248:546-556

Macey P, Miller J, Ingram BA, Cronwright MS, Botha GA, Grantham GH, Robert MR, Kock GS, Mare LP, BothaPMW, Kota M,
Opperman R, Haddon IG, Rower C (2007) Map explanation: sheets 1537 Alto Molócuè, 1538 Murrupula, 1539 Nampula, 1540 Mogincual, 1637 Errego, 1638 Gilé and 1639-40 Angoche, Ministério dos Recuursos Minerais e Energia, Direção Nacional de Geologia, Maputo, Mozambique and Council for Geoscience, Pretoria, South Africa, 392 pp

Macey P, Miller J, Rower C, Grantham G, Siegfried P, Armstrong R, Kemp J, Bacalu J (2013) Geology of the Monapo Klippe, NE Mozambique and its significance for assembly of central Gondwana. Precambiran Res 233:259-281

MCA (2013) Millenium challenge account. http://www.mca.gov.mz/ m/documents/special/en/MCA_Mozambique_Special_Report_ RuralWater.pdf. Accessed Sept 2016

Palacky G (1988) Resistivity characteristics of geologic targets. SEG 1:53-129

Portal do governo (2016) Official publication of the republic of Mozambique: Ministerial diploma nr 180/2004 of September, 15th (I serie-number 37). http://portaldogoverno.gov.mz/por/ Governo/Legislacao/Boletins-da-Republica. Accessed Sept 2016

Reynolds JM (2011) An introduction to applied and environmental geophysics, 2nd edn. Wiley-Blackwell, Chichester. ISBN 978-0471-485360

Salman G, Abdula I (1995) Development of the Mozambique and Rovuma sedimentary basins, offshore Mozambique. Sediment Geol J 96:7-14

Sharp JM (2014) Fractured rocks hydrogeology. CRC Press, USA

Singhal BBS, Gupta RP (2010) Applied hydrogeology of fractured rocks, 2nd edn. ISBN 978-90-481-8798-0, pp 139-154

Slater LD, Lesmes D (2002) IP interpretation in environmental investigations. Geophysics 67(1):77-88

Strahler A (1971) The earth science. A Harper International edition, 2nd edn, CDN 78-127335

Wright EP (1992) The hydrogeology of crystalline basement aquifers in Africa. Geol Soc Spec Publ 66:1-27 